\title{
Religiosity: Towards A Conceptualization and An Operationalization
}

\author{
Y Anuradha Iddagoda \\ PhD Candidate \\ University of Sri Jayewardenepura \\ HHDNP Opatha \\ Senior Professor \\ Department of Human Resource Management \\ University of Sri Jayewardenepura
}

\begin{abstract}
Religiosity is closely interwoven with the lives of Sri Lankan citizens who are adherents of mainly Buddhist, and then Hindu, Muslim and Christian faiths. There is a growing interest in conducting research on religiosity. There are many definitions of religiosity but they need to be refined since they do not represent the whole idea of religiosity. Religiosity is defined as the extent to which the particular employee believes in and venerates the founder, gods or goddesses of the relevant religion, practices the relevant teaching and participates in the relevant activities. Religiosity involves one's being religious earnestly and really rather than one's being religious frivolously and nominally. The dimensions and elements of religiosity have been investigated with a view to developing an instrument to measure the variable of religiosity. Reliability and validity of the instrument are also presented.
\end{abstract}

Key Words: Religiosity, Conceptualization, Operationalization

\section{Introduction}

Employees are the most important resource an organization has and utilizes to achieve its goals. Generally majority of employees are following or at least belonging to a religion, particularly in Sri Lanka which is a newly industrializing country that has been implementing various macro and micro level strategies and programs to achieve its economic social and other goals. For Sri Lanka to achieve her goals effectively from the point of national level and for organizations to achieve their goals effectively from the point of organizational level employees and management of employees (HRM) play critical roles. Several studies done in Sri Lanka reveal the following findings:

1. There are considerable amount of employees suffering from grievances owing to many reasons (Akuratiyagamage and Opatha, 2004) and organizations are formally concerned with employee grievance settlement (Opatha, 1994).

2. Employees have a strong need for trade union among union members in large service organizations and greater degree of participation in trade union activities (Jinadasa and Opatha, 1999) is visible. 
3. Number of strikes and man days lost are considerable (Opatha and Ismail, 2001). Unfavorable labor management relations have been attributed for low level of average productivity in the manufacturing sector (Opatha, 2005).

4. Labour relations is independent of education and experience of union officials in manufacturing firms implying a need for separate systematic attempt to improve union officials competence to make labour relations better (Opatha, 2003).

5. There is a serious need of generating, maintaining and enhancing morality within employees, in order to avoid the plight of misbehaving including frauds, corruptions, evil conflicts and retaliations (Opatha, 2010).

6. Employees need to be transformed from normal employees to green employees for preservation, conservation, non-pollution and make of looking-like natural places (Opatha, 2013).

7. As per the Gallup's study, in Sri Lanka from 2011 to 2012, 14\% employees are engaged, $62 \%$ are not engaged and $23 \%$ are actively disengaged (Iddagoda and Opatha, 2017).

The above research findings of the studies done mainly by one of the authors of this research paper reveal that the relevant Human Resource Management (HRM) phenomena in Sri Lanka need to be improved significantly. Thus an intellectual puzzle arose within us with regard to whether religiosity of employees has something to do with suffering from grievances, increased employee participation in union activities, declining labour management relationships, reduced employee morality, greening of employees and reduced employee engagement. It is interesting to find out the relationship and the impact of employee religiosity with and on the degree of employee suffering from grievances, employee participation in union activities, labour management relationships, employee morality, greening of employees and employee engagement. Little is known about such phenomena in the context of HRM.

\section{Purpose Statement}

The purpose of this paper is to present a holistic view of religiosity for future systematic empirical investigations in the field of HRM. To that end it attempts to address:

1. Towards a working definition of religiosity

2. Categories of religiosity

3. Operationalization of the construct

4. Evidence of religiosity in the Sri Lankan context

5. Reliability and validity of the construct

\section{Sources of Data}

A desk research study was performed by using many databases and books. For the desk research study, the researchers took a range of published works from 1990 to 2016. In the search of articles in order to collect the data, databases such as Taylor and Francis Online, Sage, Springerlink, ScienceDirect, JSTOR, Emerald and Wiley Online Library were used. In the same way relevant available books were studied in detail. In-order to provide the evidence of reliability and validity of the instrument a sample of 272 executives and managers of the listed companies in Sri Lanka was taken and the unit of analysis was individual. 


\section{Introduction to Religiosity}

Vitell (2010) mentions that there are similarities between religiosity and spirituality but they are different. According to Bergan and McConatha (2000), religiosity refers to various dimensions associated with religious beliefs and involvement. The Concise Oxford Dictionary (1993) defines "involve" as "to participate or share the experience or effect, include or affect in its operations". Bergan and McConatha (2000) have identified two dimensions associated with religiosity, namely, religious beliefs and involvement. Bergan and McConatha (2000) state that previous social psychological research generally evaluated religiosity as a one-dimensional concept, focusing primarily on religious attendance. Bergan and McConatha (2000) further state that reliance on religious attendance as a sole measure of religiosity may be insufficient and may lead to incorrect conclusions.

Sedikides (2009) defined religiosity as an orientation, behavioural set and lifestyle considered important by the large majority of people worldwide that cannot be neglected by social and personality psychology any longer. The statement "by the large majority of people worldwide" is not acceptable. There can be a religion that a small number of people believe in. They also have religiosity. King and Williamson (2010) state that religiosity is also known as religiousness. They define religiosity as the strength of one's connection to or conviction for their religion. "One's connection" is like a bond to the religion. "Conviction for their religion" means belief in their religion. The Pocket Oxford English Dictionary (2007) defines "religious" as "relating to or believing in a religion". Since King and Williamson (2010) state that religiosity is also known as religiousness, their definition covers the aspect called "the extent a person believes in that religion".

According to Adeyemo and Adeleye (2008), religiosity includes having belief in, reverence for God or a deity, as well as participation in activities in that faith, such as attending service/worshipping regularly and participating in other social activities with one's religious community. As defined by Adeyemo and Adeleye (2008), "God or a deity" is not acceptable for some cases. There are some religions that do not believe in following a specific God or a deity. The devotees of those religions believe in and practice what the founder of the religion preached. The founder of the religion can be a god or not a god. For instance, in Buddhism the Buddha is the founder of the religion and the Buddha is not a God. It is also evident that some Buddhists do not worship gods and some do. As Adeyemo and Adeleye (2008) state in their definition "participating in other social activities with one's religious community" is an essential component of religiosity.

Exhibit 1: Definitions of Religiosity

\begin{tabular}{lcll}
\hline Author & Year & Definition & Comments \\
\hline $\begin{array}{l}\text { Bergan and } \\
\text { McConatha }\end{array}$ & 2000 & $\begin{array}{l}\text { Religiosity refers to the various } \\
\text { dimensions associated with } \\
\text { religious beliefs and } \\
\text { involvement. }\end{array}$ & $\begin{array}{l}\text { Identified two dimensions associated with religiosity, } \\
\text { namely, religious beliefs and involvement or } \\
\text { participation. }\end{array}$ \\
Sedikides & 2009 & $\begin{array}{l}\text { An orientation, behavioral set } \\
\text { and lifestyle considered } \\
\text { important by the large majority } \\
\text { of people worldwide. }\end{array}$ & $\begin{array}{l}\text { The statement "by the large majority of people } \\
\text { worldwide" is not acceptable because there can be a } \\
\text { religion that a small number of people believe in. } \\
\text { They also have religiosity. }\end{array}$
\end{tabular}




\begin{tabular}{lcll}
$\begin{array}{l}\text { King and } \\
\text { Williamson }\end{array}$ & 2010 & $\begin{array}{l}\text { The strength of one's connection } \\
\text { to or conviction for their } \\
\text { religion. }\end{array}$ & $\begin{array}{l}\text {-"One's connection" is like a bond to the religion. } \\
\text { - "Conviction for their religion" means belief in their } \\
\text { religion. }\end{array}$ \\
$\begin{array}{l}\text { Adeyemo and } \\
\text { Adeleye }\end{array} 2008$ & $\begin{array}{l}\text { Religiosity includes having } \\
\text { belief in and reverence for God } \\
\text { or a deity, as well as } \\
\text { participation in activities in that } \\
\text { faith, such as attending } \\
\text { service/worshipping regularly } \\
\text { and participating in other social } \\
\text { activities with one's religious } \\
\text { community. }\end{array}$ & $\begin{array}{l}\text { - "God or a deity" is not acceptable in some cases. } \\
\text {-There are some religions that do not believe in } \\
\text { following a specific God or a deity. The devotees of } \\
\text { those religions believe in and practice what the } \\
\text { founder of the religion preached. }\end{array}$ \\
\hline
\end{tabular}

The researchers assert that religiosity consists of three components:

1. Piety - Belief in and reverence for.

2. Practice - Practice what the religion or the founder of the religion preached.

3. Participation in activities - Participation in activities in observing the religion and participating in other social activities with one's religious community.

First, a person should have piety. The Pocket Oxford English Dictionary (2007) defines piety as a conventional belief accepted without thinking. A person should believe and have reverence for the founder of the religion and what he preaches without having a doubt. Then he/she should practice what the founder of the religion preached. For example, a Buddhist has to practice the Five Precepts daily and Eight Precepts on the full moon Poya day. Similarly, he/she should practice Sigalovada Sutta, also known as Gihi Vinaya or Code of Discipline for Laymen. He/she should participate in activities in observing the religion and worshipping the founder of the religion, religious leaders and the objects that have a religious significance. Furthermore, a particular person ought to participate in other social activities with one's religious community.

An employee who has a religion may not be a devout (A person who strongly follows that religion). There are some employees who say that they are religious but do not actually engage in practicing the relevant religious teaching. Hence to have religion and to follow a religion are different, not the same. For example there are Buddhists who do not actually practice the Buddha's teaching but they called Buddhists because of the mere fact that they belong to Buddhism or their parents are Buddhists. Being religious really is far different from being religious nominally.

By considering all the above mentioned details, it is possible for the researchers to present here a new definition of religiosity.

\section{Religiosity- Working Definition}

Religiosity is defined as the extent to which a particular employee believes in and venerates the founder, gods or goddesses of the relevant religion, practices the relevant teaching and participates in the relevant activities. Religiosity involves one's being religious earnestly and really rather than one's being religious frivolously and nominally. 


\section{Categories of Religiosity}

The researchers define five categories of religiosity, namely, very high religiosity, high religiosity, moderate religiosity, low religiosity and very low religiosity.

Very high religiosity: People in this category participate excessively in religious activities. Their belief in a religion is very high. Also, they have a very positive feeling and respect for religious personages (monks, priests, sadhus, etc.). They follow customary religious ceremonies on important occasions in their lives. In the case of Sri Lankan Buddhists this is similar to holding an alms giving on important occasions, such as the building of a new house, on a child's first birthday, prior to a marriage and on the death anniversary of a loved one. They also go to religious shrines regularly, not only on days of religious significance but on other days as well.

High religiosity: Participation in religious activities is at a high level. Their belief in a religion is high, but less than in the very high category. They go to religious shrines only on the days which have a religious significance. For instance, a Buddhist goes to temple only on full moon Poya days. A Christian goes to church on Sundays.

Moderate religiosity: They believe in a religion in a moderate level. Therefore participation in religious activities of these people is moderate. They go to the religious shrines only on the days which have a higher religious significance. For instance a Christian who does not go to the church on every Sunday may go to the church only for Easter, Good Friday or Christmas. A Buddhist who does not go to the temple on every full moon Poya day goes to the temple only on Vesak Poya day (the most important full moon Poya day which commemorates the birth, enlightenment and death of The Buddha).

Low religiosity: Participation in religious activities is at a low level since their belief in a religion is low. They rarely go to religious places. They attend religious ceremonies as a commitment. For instance, they just go to an all-night pirith chanting ceremony in their neighborhood because they must go; in other words, due to commitment. (Pirith chanting is an ancient practice. Discourses of the Buddha are recited at all-night pirith ceremonies).

Very low religiosity: Their belief in a religion is at a very low level. They would say, "I have no religion and I'm an agnostic."

\section{Dimensions of Religiosity}

Operationalization of the Variable of Religiosity

Religiosity is conceptualized as a system that fundamentally consists of three dimensions: piety, practice and participation.

\section{Dimension 1: Piety}

Piety is devotion to a particular religion. One who has piety becomes devoted to the religion he or she observes. The person who has piety has a belief in his or her religion and tends to behave in the way that has been prescribed by his or her religion. This dimension can be measured by using elements such as (1) belief-degree of believing in preaching of the founder of the religion and (2) reverence-nature of feeling and respect for the religion and religious personages (monks, 
priests, sadhus, etc.). Exhibit 2 presents the elements and statements of the dimension called piety.

Exhibit 2: Elements and Statements of the Dimension- Piety

\begin{tabular}{ll} 
Element & Statement \\
\hline Belief & I believe in what the founder of my religion preached.
\end{tabular}

Reverence I have a very positive feeling and respect for religion and religious personages (monks, priests, sadhus, etc.).

\section{Dimension 2: Practice}

Practice is following the religion by action. One who has practice does carrying his or her religion in accordance with his or her beliefs and prescriptions of the religion. This dimension can be measured by elements such as (1) the degree of practicing the preaching of the founder of the religion, and (2) degree of concern with practicing. Exhibit 3 presents the elements and statements of the dimension called practice.

\section{Exhibit 3: Elements and Statements of the Dimension- Practice

Element Statement \\ Practice what founder of the I practice what the founder of my religion preached. \\ religion preached \\ I am more concerned about practicing what the religious books prescribe and engage in whole hearted way.}

\section{Dimension 3: Participation}

Participation means being involved in religious activities. Every religion has certain activities recommended for the devout to be involved with. It is possible to measure this dimension by using elements such as (1) frequency of going to religious places to worship/pray, (2) involvement in religious ceremonies owing to knowing their importance and (3) involvement in other religiously important activities. Examples include pirith chanting ceremonies, church feasts, religious processions, etc. Exhibit 4 presents the elements and statements of the dimension called participation.

\section{Exhibit 4: Elements and Statements of the Dimension-Participation}

\begin{tabular}{ll}
\hline Element & Statement \\
\hline Worship regularly & I very often go to religious places to worship/pray. \\
$\begin{array}{l}\text { Participating in other social } \\
\begin{array}{l}\text { activities which have a } \\
\text { religious significance }\end{array}\end{array}$ & $\begin{array}{l}\text { I participate in religious ceremonies because I know their religious significance. } \\
\text { Include pirith chanting ceremonies, church feasts, religious processions, etc. }\end{array}$
\end{tabular}

Figure 1 presents the dimensions and elements of the variable of religiosity. In the Figure 1 "D" stands for dimension and "E" stands for element. Based on the statements given in Exhibit 2, 
Exhibit 3 and Exhibit 4, it is possible to develop an instrument to measure the construct of religiosity.

\section{Figure 1: Dimensions and Elements of the Variable of Religiosity}

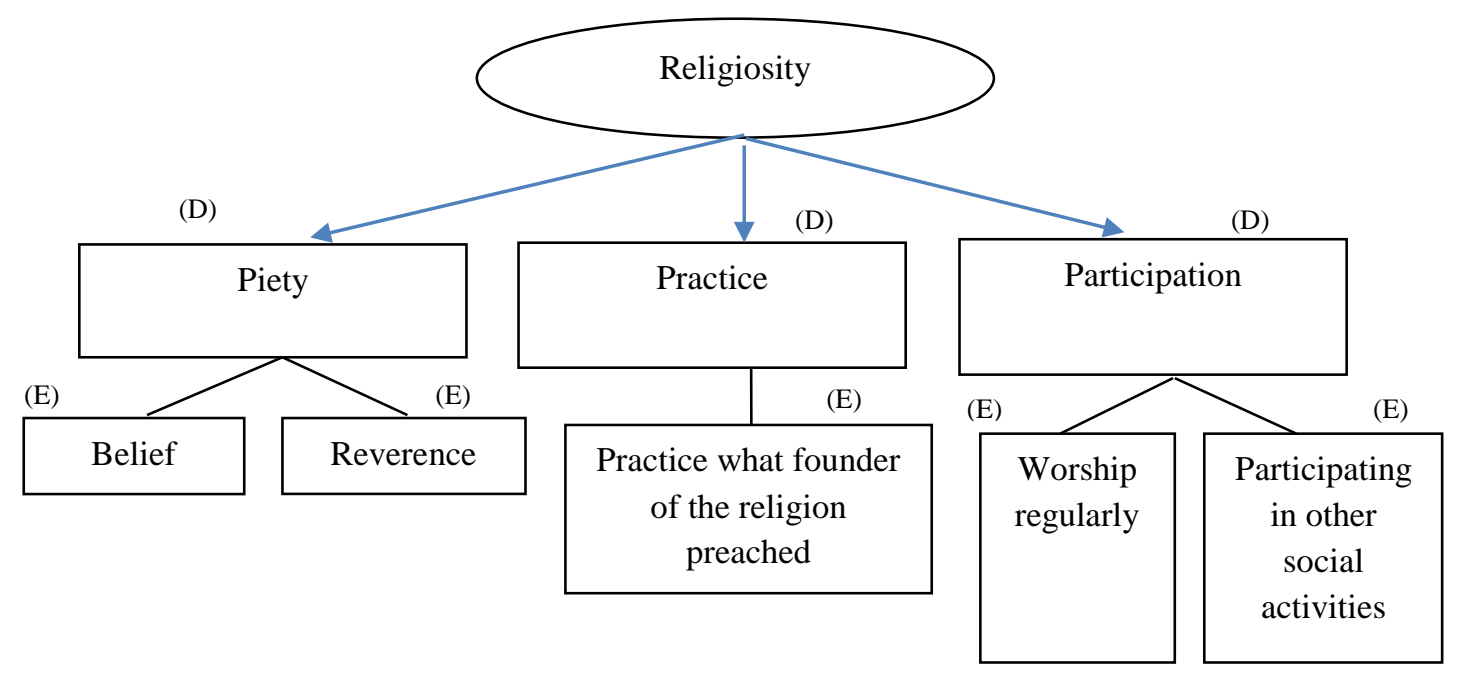

\section{Evidence of Religiosity in Sri Lanka}

According to the Department of Census and Statistics, the Census of Population and Housing of Sri Lanka, (2011), Buddhism represents $70.19 \%$ of the population of Sri Lankans. Hinduism $12.61 \%$, Islam $9.71 \%$, Christianity $7.45 \%$ and other religions represent $0.04 \%$ of the population. Sri Lanka has a very high number of religious public holidays counting the 12 or 13 Poya holidays per year. The sale of liquor on Poya days and public entertainments such as cinema and theatre are also prohibited. There are eight public holidays per year in Sri Lanka. Four of them have a religious significance. They are Thai Pongal day, the day following Vesak Poya day, the Holy Prophet Mohammed's Birthday, and Christmas Day. The emphasis on the importance of religious education both in religious school or Sunday school, which is known as Dahampasala, and in government schools, where religion is a compulsory subject, also provides evidence of religiosity.

Sri Lanka is a very religious-minded country by all accounts. Gallup (2010) report reveals that in Sri Lanka in 2009, 99\% said religion is an important aspect to their life. Ubiquitous religious shrines and religious signs are demonstrations of religiosity in a country and in Sri Lanka it is possible to observe the ubiquitous presence of Buddhist temples mostly, Hindus kovils, Moslem mosques and Christian churches all over the country. In every village, there is a religious shrine demonstrating the religious ethos of the village. In addition to wayside shrines, there is an abundance of religious signs and symbols of religion such as statues of the Buddha mostly, Jesus Christ, Virgin Mary, a variety of Catholic Saints and Hindu deities, open to public veneration.

In the West, going to religious places such as churches has dropped dramatically, but in Sri Lanka it is the opposite. A significant number of devotees gather at religious shrines to pay 
homage. Christians go to the churches every Sunday to participate in Holy Mass. Large numbers of Buddhist devotees gather at temples on Poya days (full moon) to observe ata sil (the eight Buddhist precepts), listen to Dhamma sermons and to make various symbolic offerings to the "Triple Gem". It is not only on Poya days that devotees are seen in temples; they are also seen on other days too. They usually perform Bodhi pooja (veneration of the Bodhi-tree (pipal tree: ficus religiosa). Devotees believe that Bodhi pooja will help them to achieve success in their material life as well as in their spiritual life. Muslims go to the mosque every Friday and Hindus go to the Kovil on festival days.

Most of the Buddhists go on an annual pilgrimage to sacred places like Dambulla, Anuradhapura, Polonnaruwa and Kandy in Sri Lanka. Thousands of Roman Catholics attend the feast at the Madhu Church in August every year. The shrine of Our Lady of Madhu is a Roman Catholic Marian shrine in Mannar district of Sri Lanka. Hindus in Sri Lanka go on pilgrimage to five prominent temples dedicated to Lord Shiva. People in Europe, Australia and New Zealand etc, visit other countries sightseeing but Sri Lankans prefer visiting foreign countries on pilgrimage. Sri Lankan Buddhists go to India and Sri Lankan Muslims go to Mecca in Saudi Arabia on pilgrimage. Sri Lankan Christians visit the Holy Land (Israel) and Sri Lankan Hindus visit India, especially Tamilnadu, on pilgrimage.

There is a tradition of religious processions on public roads on occasions of religious importance: celebration of Catholic Church feasts, Buddhist processions such as the Esala procession of Kandy, and the Vel (chariot) festival of Hindus, etc. These processions are accompanied by singing, chanting, dancing and drumming, etc. as an expression of devotion.

Invoking the blessings of the deities on important occasions is a practice among laymen and the public in Sri Lanka. The President, Ministers and other public figures engage in religious observance to invoke divine blessings on important occasions. The national cricket team receives traditional religious blessings before setting off on a foreign tour. These are broadcasted over the media. Before a marriage ceremony there is a custom for the couple to invoke religious blessings.

Customary Buddhist ceremonies also provide evidence of religiosity in Sri Lanka. Berkwitz (2003) points out that it is customary for Sri Lankan Buddhists to hold an alms giving (dana) on important occasions such as on a child's first birthday, prior to a marriage, building a new house and on the death anniversary of a loved one.

Unlike in European countries, hardly any Sri Lankan would say, "I have no religion and I'm an agnostic", except for a handful of rationalists. There is, in general, a very positive feeling and respect for religion and religious personages such as monks, priests and sadhus, etc. The existence of charismatic monks is also a sign of a high level of religiosity. Berkwitz (2003) mentions that Ven. Uduwe Dhammaloka is a popular urban monk because of his charismatic preaching style. Ven. Gangodawila Soma Thero and Ven. Panadure Ariya Dhamma Thero are also charismatic monks who lived decades ago.

Berkwitz (2003) reveals that the spread of new technologies, such as the Internet and satellite television, helps the Sri Lankan Buddhist to access a variety of cultural and religious 
programmes. New technologies such as the Internet and satellite television are enabling the telecast of their religious programmes, also. This is applicable to other main religions such as Christianity, Hinduism and Islam, too.

In his article titled "The Sri Lankan Post-modern Consumer", Liyanage (2010) talks about a "Modtradi" consumer and religious pirith nool. Pirith is a narration or chanting of the words of the Buddha. Pirith nool is an enchanted blessing string that has been strengthened by chanting pirith. According to Liyanage (2010), a "Modtradi" consumer is dressed in a faded pair of jeans, branded T-shirt, and the thick and showy pirith nool for beautification. Liyanage (2010) further states that the "Modtradi" consumer ties the pirith nool, thick and showy, around his/her wrist as a symbol of traditionalization and the pair of faded jeans as an expression of modernity.

The availability of religious books, religious articles, religious bookshops and the establishment of universities with religious significance are also evidence of a high level of religiosity.

\section{Reliability and Validity of the Religiosity Instrument}

The sample size was 272 executives and managers of the listed companies in Sri Lanka. The variable of religiosity was delineated into three dimensions namely piety (with two elements measured by 2 question statements), practice (with one element measured by 2 question statements) and participation (with two elements measured by 3 question statements). In other words the construct of religiosity consists of seven question items representing the three dimensions. Sekaran (2003) states that content validity is a function of how well the dimensions and elements of a concept have been delineated. The researchers have ensured content validity through sound conceptualization and operationalization. The researchers ensured construct validity of the construct of religiosity. Nunnally (1978) recommends a 10 to 1 ratio: that is, 10 cases for each item to be factor analyzed. Tabachnick \& Fidell (2001) recommend a 5 to 1 ratio: that is, 5 cases for each item to be factor analyzed. Pallant (2005) in his study acknowledged these ratios, 0.5 or above is the recommended level for factor loading (Dubey, 2016; De Vries, 2012). Even though theoretically there are three latent variables under religiosity, the first and second latent variables i.e. piety and practice had two items each and the third latent variable i.e. participation had three items. The items fell under one factor with higher factor loadings. By considering all these decision has been taken not to drop any item based on these results. The data forwarded to check the reliability of the instrument.

Cronbach's Alpha reliability needs to be sufficient to avoid reducing the statistical power of the instrument in data analysis. The seven items used to tap the meaning of religiosity of this variable have been highly correlated. The Cronbach's Alpha reliability coefficient was 0.845 suggesting that the instrument possesses an adequate degree of interitem reliability. The statistical output related to internal consistency reliability and content validity of religiosity can be summarized in Table 1. 
Table 1: Reliability and Validity of the Construct

\begin{tabular}{lllll}
\hline Variable & Items & $\begin{array}{l}\text { Principal } \\
\text { Component of } \\
\text { Factor Loading }\end{array}$ & $\begin{array}{l}\text { Cronbach's Alpha } \\
\text { if Item Deleted } \\
\text { Reliability } \\
\text { Coefficient }\end{array}$ & $\begin{array}{l}\text { Cronbach's Alpha } \\
\text { Reliability } \\
\text { Coefficient ( } \boldsymbol{\alpha})\end{array}$ \\
\hline Religiosity & REL1 & 0.592 & 0.769 & 0.845 \\
& REL2 & 0.708 & 0.747 & \\
REL3 & 0.603 & 0.765 & \\
REL4 & 0.582 & 0.769 & \\
REL5 & 0.651 & 0.757 & \\
& REL6 & 0.782 & 0.724 & \\
REL7 & 0.694 & 0.749 & \\
\hline
\end{tabular}

Source: Survey data

\section{Conclusion}

There are five categories of religiosity: very high religiosity, high religiosity, moderate religiosity, low religiosity and very low religiosity. Piety, practice and participation in activities are the dimensions of the variable of religiosity. Certain elements under each dimension can be identified and they could be used to develop an instrument to measure religiosity. The researchers have also attempted to provide evidence of religiosity in Sri Lanka in general way. Validity and reliability of the instrument developed to measure religiosity were adequate.

\section{References}

Adeyemo, D.A. and Adeleye, A.T., (2008), Emotional intelligence, religiosity and self-efficacy as predictors of psychological well-being among secondary school adolescents in Ogbomoso, Nigeria, Europe's Journal of Psychology, Vol.4, No.1.

Akuratiyagamage, V. M. and Opatha, H. H. D. N. P. (2004), Grievances of middle managers: an empirical investigation into perceptions of commercial bank branch managers in Sri Lanka, Journal of Management Research, Vol.4, No.2, pp. 99-112.

Bergan, A. and McConatha, J.T. (2001), Religiosity and life satisfaction, Activities, Adaptation and Aging, Vol.24, No.3, pp.23-34.

Berkwitz, S.C. (2003), Recent trends in Sri Lankan Buddhism, Religion, Vol.33, No.1, pp.57-71.

Commerce, University of Sri Jayewardenepura, pp. 22-41.

Concise Oxford Dictionary, (1993),OXFORD UNIVERSITY PRESS.

De Vries, D. (2012), Leveraging Patents Financially: A Company Perspective, Springer Science \& Business Media.

Department of Census and Statistics, the Census of Population and Housing of Sri Lanka, (2011). http://www.statistics.gov.lk/pophousat/cph2011/

Dubey, R. ed. (2016), Strategic Management of Sustainable Manufacturing Operations, IGI Global.

Gallup, (2010), Religiosity Highest in World's Poorest Nations. Available from:http://www.gallup.com/poll/142727/religiosity-highest-world-poorestnations.aspx Retrieved August, 12, 2013.

Iddagoda, Y. A. and Opatha, H. H. D. N. P. (2017), Identified Research Gaps in Employee Engagement, International Business Research, Vol.10, No. 2, pp.63-73. http://dx.doi.org/10.5539/ibr.v10n2p63. 
Jinadasa, P.C.V. and Opatha, H.H.D.N.P. (1999), An Empirical Study of Membership Participation in Trade Union Activities: Evidence from Selected Service Organizations in Sri Lanka, Sabaragamuwa University Journal, Vol.2, No.1, pp.17-34.

King, J.E. and Williamson, I.O. (2005), Workplace religious expression, religiosity and job satisfaction: Clarifying a relationship, Journal of management, spirituality \& religion, Vol.2, No.2, pp.173-198.

Liyanage, U. (2010), The Sri Lankan post-modern consumer, Sri Lankan Journal of Management, Vol.14, No.15, pp.4-.

Nunnally, J. C. (1978), Psychometric Theory (2nd ed.), New York: McGraw-Hill.

Opatha, H. H. D. N. P. (1994), Employee grievance settlement procedure: a case study of two corporations, Management Review, Vol.1, No.2, pp.53-60.

Opatha, H. H. D. N. P. (2003), Is labour relations dependent on education, industrial relations education and experience of union officials? An empirical study on ten manufacturing firms in Sri Lanka, Journal of Management, Vol.1, No.1, pp.1-10.

Opatha, H. H. D. N. P. (2013), Green Human Resource Management: A Simplified Introduction HR Dialogue-2013, Proceedings of HR Symposium, Department of HRM, Faculty of Management Studies and Commerce, University of Sri Jayewardenepura, pp. 22-41.

Opatha, H. H. D. N. P. and Ismail, Z. (2001), Towards effective worker grievance handling: some reflections, Analisis, Vol.8, No.1\&2, pp.111-127.

Opatha, H.H.D.N.P. (2010), Personal Quality, Dept of HRM, University of Sri Jayewardenepura.

Opatha, H.H.D.N.P. and Zakaria B. Ismail. (2005), An Empirical Investigation of Managementrelated Factors Contributing to Labour-Management Relationship in Manufacturing Firms in Sri Lanka, NMIMS Management Review, Vol.14, No.1, pp.74-85.

Pallant, J. (2005), SPSS survival manual, McGraw-Hill Education (UK).

Pocket Oxford English Dictionary, (2007), OXFORD UNIVERSITY PRESS.

Sedikides, C. (1970), Why does religiosity persist?, Personality and Social Psychology Review, 14(1), pp.3-6.

Sekaran, U. (2003), Research methods for business: A skill building approach, John Wiley \& Sons.

Tabachnick, B. G. and Fidell, L. S. (2001), Using multivariate statistics (4th ed.), Needham Heights, MA:Allyn \& Bacon.

Vitell, S.J. (2009), The role of religiosity in business and consumer ethics: A review of the literature, Journal of Business Ethics, Vol.90, pp. 155-167. 